\title{
IMAGENS SIMBÓLICAS DA CONQUISTA DA TERRA DOS BRASIS
}

\author{
Paulo de Assunção*
}

\begin{abstract}
RESUMO: A conquista da Terra dos Brasis nos mostra a necessidade de integração das novas terras ao contexto europeu do século XVI. O estudo das imagens simbólicas religiosas, feitas pelos primeiros jesuítas, permite compreender o alcance das idéias utilizadas para explicar o complexo universo de afinidades entre Europa e América. As diferenças e similaridades foram compreendidas através de exemplos bíblicos, que revelam os mecanismos de leitura da superioridade e inferioridade, que caracterizou a interação cultural e a relação de poder no século XVI.

ABSTRACT: The conquest of Brasis Land shows us the necessity of the integration of the new lands in the european context of the XVI century. The study of religious symbolic images, done by the first Jesuits, allows us to understand the reach of the ideas that were used to explain the complex universe of the relationship between Europe and America. The differences and similarities were comprehended by means of biblical examples, which reveal the reading mechanisms of superiority and inferiority, that characterized the cultural interaction and the power relation in the XVI century.
\end{abstract}

PALAVRAS-CHAVE: Conquista da América, Brasil, Jesuítas, simbolismo religioso.

KEYWORDS: Conquest of America, Brazil, Jesuits, religious symbolism.

As descobertas marítimas romperam com o enclausuramento das partes do mundo conhecido, alterando os ritmos da vida cotidiana dos indivíduos dos séculos XV e XVI.

Os descobrimentos, ao revelarem a verdadeira dimensão do globo terrestre para a humanidade, desencadeiam um novo reordenamento das estruturas de pensamento, uma mudança histórica até en-

* Doutorando pelo Departamento de História - FFLCH/USP tão nunca vista. $\mathrm{O}$ palco da atuação humana era ampliado, assim como o seu conhecer, sendo que essa "novidade-mudança" é responsável "por um novo mundo de coisas, informações, dados, diferenças, etc"(BARRETO, 1987, p.41).Como observou Carvalho, as descobertas prepararam o caminho para uma nova ciência, o homem despertava para sua consciência crítica, desterrando do saber os erros longamente enraizados no pensamento europeu (CARVALHO, 1947, p.12). 
A Europa conhecia-se e avaliava-se em função da emergência das novas culturas, que paulatinamente iam sendo identificadas, tendo sido impulsionadas e expandidas pelo surgimento e desenvolvimento da imprensa. Um novo sistema de pensamento era construído em consonância com o progresso material (CARVALHO, 1947, pp. 21-50).

As diferentes formas de vida encontradas revelavam que a civilização européia não era única nem tampouco seus valores eram os dominantes. Como observou Barreto:

"os descobrimentos foram uma imensa explosão dos limites da terra e do mar, uma nova e maior extensão dos horizontes e modalidades de comunicação intercivilizacional" (BARRETO, 1987, p.10).

Como toda explosão abala estruturas, os descobrimentos solaparam as bases européias de interação sociocultural, até então apoiadas exclusivamente num caráter bélico de relacionamento.

A reordenação do saber era uma condição sine qua non, frente a um processo desmoronadiço do pensamento europeu. O Velho Continente era mais instável e mais vulnerável aos deslocamentos e reconhecimentos contínuos que o mundo assumia, fazendo como que uma outra lógica fosse inventada.

O conceito proposto por O'Gorman para a leitura da elaboração do pensamento ocidental, do aparecimento histórico da América, é sintetizado pelo autor com o termo "invenção". Para a leitura do novo, O'Gorman revela que as terras americanas não podiam contradizer a idéia dogmática cristã da existência de um Deus único necessário. Desta forma, a origem do mundo se confunde com a própria invenção da América pois, "a idéia de universo inclui a totalidade de tudo quanto existe; o conceito de globo terrestre refere-se ao nosso planeta mas, na época considerada, referi-a à nossa de matéria cósmica mais pesada, porque nela prevalecia a essência ou o elemento terra. $\mathrm{O}$ mundo não é, primariamente, nem uma coisa nem outra. É antes de tudo, a morada cósmica do homem, sua casa ou domicílio no universo, antiga noção que os gregos definiram com o termo ecúmeno. O mundo, pois, certamente supõe um sítio e uma determinada extensão, mas seu traço definidor é de natureza espiritual”' (O'GORMAN, 1992, p.87).

O reconhecimento de novas culturas, se por um lado, permitiu a ampliação dos horizontes econômicos e da possibilidade de um desenvolvimento mercantil mais acentuado, por outro, alterou os padrões comportamentais como um todo, a começar por aqueles advindos da própria condição das descobertas. A vida do navegante, transeunte dos mares, será a brecha vital que ao mesmo tempo em que rompe condições existentes, instaura uma nova circulação de informações e de cultura nunca antes experimentada.

Circulação cultural é, sem dúvida, o termo que melhor define transações e interações que se processaram com os descobrimentos nos Quinhentos e Seiscentos. O homem até então confinado à Europa, ao norte da África e parte do Oriente, com as descobertas, vê o limite do seu universo ampliado sensivelmente; diferenças e similaridades exteriorizamse, necessidades e abundâncias delineiam-se, o perto e o distante relativizam-se, o mundo torna-se ecumênico na própria acepção da palavra, e da mentalidade religiosa da época.

A universalização impõe a ampliação da rotatividade cultural. O conhecimento não é mais uno e sim múltiplo, pois múltipla é a experiência vivida que deve ser transmitida, tal como os produtos são trocados no comércio. O Cosmo ganha vitalidade. A circulação, que implica a possibilidade do novo, é a redescoberta de uma origem similar àquela do momento primordial da criação.

Os descobrimentos, ao permitirem um re-conhecimento do mundo, traziam consigo uma nova leitura da existência humana. A Igreja, detentora do saber primordial sobre as origens da civilização ocidental, 
redireciona suas explicações. $\mathrm{O}$ microcosmo medieval é implodido, e surge um macrocosmo que o pensamento cristão tem que reordenar. O novo precisava ser inserido no discurso religioso das Escrituras Sagradas, como parte componente dissociada da célula materna, algo perdido que era achado.

As terras americanas acenavam para um reencontro das partes, até então desunidas, há muito imaginado e pouco crível. Só uma lógica as envolvia, pois uma única razão as tinha tornado possível; o ponto comum entre ambas, nesse contexto, era que o monoteísmo cristão reunia de maneira convergente, todas as coisas criadas pelo ente divino. Deus era o centro do universo. Conforme observou Theodoro:

"A América, o novo mundo, é exótica apenas na sua aparência, pois faz parte da grande obra de criação, contendo, em essência, a mesma verdade que está no relato bíblico" (THEDORO, 1992, p.47).

A verdade fundamental do católico, enquanto universal, atingia sua amplitude máxima, nascia a certeza de que o grande articulador e controlador divino ofertara ao homem a possibilidade de conhecer os seus pares, regulados por uma mesma ordem e uma mesma regra geral que era o cristianismo. Desta forma, apresentava-se aos olhares curiosos da época como uma dádiva divina. Deus oferecera senão o Paraíso, pelo menos algo muito próximo de uma situação idílica, há muito tempo desejada. As novas terras são inseridas num contexto religioso de concepção que entendia que o universo, feito por Deus, é ampliado pelo engenho do homem europeu. As descobertas eram o sinal de uma nova era. $\mathrm{O}$ homem conseguia contemplar a onipotência divina e sua criação na sua plenitude ${ }^{1}$.

1. Thevet afirmava: "tornou-se a navegação pouco a pouco tão comum entre os homens, que muitos, passando mesmo além de incertas e perigosas ilhas, alcançaram por fim a boa e fértil terra firme, realizando um feito que, pelo que se deduz dos textos antigos, não foi nunca dantes igualado" (THEVET, 1988, p. 17).
O surgimento de um outro elemento totalmente desconhecido, frente à identidade européia, gerou a necessidade de introduzir um processo de transformação ou aproximação que significava a inserção do novo dentro do velho mundo, que se consolidara com a preponderância do modelo europeu. Estruturas e regras foram sistematizadas, semelhanças foram ressaltadas, diferenças atenuadas, a sistematização do saber das Escrituras Sagradas orientou para que se criasse um conjunto comum de regras e práticas necessárias para um convívio harmonioso.

Há um reducionismo que conduz a humanidade da diferença à identidade, e sendo a humanidade cristã, segundo a ótica européia, há uma "planetarização global e total do cristianismo" (BARRETO, 1987, p.39).

A Igreja, enquanto instituição modelar, assumia o grande papel que as descobertas lhe reservara, quanto a constituir as amarras de ligação com fios tênues, permitindo um trânsito cultural, ao mesmo tempo que se efetivava a aculturação do continente americano a partir do modelo eurocêntrico cristão. A cristandade descobre a existência de um outro universo, povoado de não cristãos até há pouco tempo inimaginável, mas desde a origem inferior, por não ser cristão. Este posicionamento etnocêntrico europeu tendeu a aprofundar os mecanismos de leitura do "Outro" sempre como inferiores, pelo seu distanciamento do padrão matriz europeu, pois a concepção medieval não permitia uma concepção de mundo que não fosse a do "orbis christianus" (PAIVA, 1982, p.61).

Essa alteração ou reordenação da estrutura mental européia de incorporação do novo/desconhecido, ou seja, do "novus/alter", dentro do "orbis" processou-se de maneira morosa no seio do corpo social. A sociedade européia, baseada na concretitude vivencial, demoraria a desenvolver novos raciocínios científicos inaugurados com o renascimento. Preponderavam ainda os limites da analogia e semelhanças para a descrição das coisas do mundo. 
A Igreja e suas instituições, consideradas como difusoras, definiam o padrão de identidade cristã da qual a expansão, especialmente a expansão colonial dos portugueses, surge "como concretização histórico-humana de desígnios e projetos transcendentes-absolutos" (BARRETO, 1987, p. 38).

O papel desenvolvido por Portugal nesse processo de expansão, além de ser decisório para o rompimento dos estreitos limites que envolviam o homem europeu, contribuiu para consecução da circulação cultural. Barreto afirma que

“Os portugueses são os olhos do mundo e ouvidos da Europa, o comunicador intercivilizacional por excelência da cristandade" (BARRETO, 1987, p.56).

O reino português, sistematizador de teorias e difusor de conhecimentos, concentrou um conhecimento técnico e empírico entremeado pela religiosidade cristã, fórmula que extrapolou os limites da epistemologia teórica e foi disseminado pelo mundo, pela praticidade dos portugueses. Conforme afirmou Holanda, os marinheiros e exploradores portugueses do período, tendo a experiência como mestra, constituíam "os olhos que enxergam, as mãos que tateiam" e que iriam mostrar "constantemente a primeira e última palavra do saber" ao mundo (HOLANDA, 1959, p.11).

Se os portugueses eram os olhos do mundo e os ouvidos da Europa, como afirmou Barreto, sem dúvida os jesuítas compunham de forma complementar, o paladar e o olfato da cristandade portuguesa e européia, através dos quais a comunicação intercivilizacional se processou.

O século XVI, com as descobertas, revelou a Portugal e à Europa, pela visão e audição, um requestionamento cultural e religioso. $\mathrm{O}$ novo necessitava ser assimilado dentro do todo, até então conhecido, e sua inserção se deu através das similitudes. O olhar europeu busca no novo elementos que possam identificar marcas comuns a ambos os universos, empre- endendo aproximações e reforçando a cultura cristã como superior.

A grande dificuldade desse processo é que o novo, pela existência autônoma que lhe é peculiar, possui um grau de dessemelhança grande em relação ao universo europeu. Por conseguinte, partindose de uma visão eurocêntrica, os demais povos eram vistos em função da proximidade em que se encontravam do modelo padrão, tido como civilizado, e a não proximidade apontava para um estágio primitivo humano (PAIVA, 1982, p.23).

Os jesuítas, imbuídos de fundamentos teológicos medievais, principalmente aqueles que norteavam as ações das cruzadas, consideravam, dentro desta perspectiva, que sua missão era cristanizar e aumentar o universo cristão, respeitando e ampliando a ordem dos governos vigentes que possibilitaram a atuação da Companhia. Eram eles os "guerreiros de Cristo" na luta para a expansão das asas da caridade, da fé católica, e do poderio econômico expancionista europeu (LEITE, 1954, vol. I, p.313).

O papel do inaciano tendeu a ser um elo de ligação e equilíbrio entre as partes componentes da sociedade e, por conseguinte, mantenedor e defensor da legitimidade dos governos nacionais nas terras americanas. A Companhia de Jesus agia para garantir o bom funcionamento do corpo social e da conversão destes para o catolicismo.

Mediadores entre o espiritual e o temporal, o poder reivindicatório dos jesuítas era limitado. Conciliadores, por formação, não procuraram tecer articulações que abarcassem grandes propostas radicais junto à sociedade. Voltados para um passado ideal, essencialmente guerreiro, as propostas restringiamse a projetos conciliatórios frente às mudanças, as quais inevitavelmente tenderam a se compor com o da ordem econômico-política vigente, pois dela advinha a sustentação da Companhia. O Novo Mundo era amarrado ao continente europeu, como parte secundária de uma máquina já em funcionamento. 
A própria formação jesuítica apontava que o papel do futuro companheiro de Jesus deveria ser mais o de um facilitador, entre o humano e o divino, do que propriamente um questionador da estrutura de desigualdade social ou da garantia dos povos recém-achados.

Os Exercícios Espirituais, escritos por Loyola, não constituíam uma elaboração teórica sobre o cristianismo frente às novas descobertas nem pretendiam defendê-lo dos ataques que vinha sofrendo. Os Exercícios, muito mais pragmáticos do que teóricos, visavam antes de mais nada a reunir o ser humano ao seu criador, afastado por motivos terrenos (advindos da intensificação do mercantilismo e das descobertas), conclamando o ser humano ao discernimento e à aproximação com Deus. Partindo do pressuposto de que a condição humana era pecadora, por não reverenciar a Deus, os Exercícios se apresentavam como uma atividade controlada e metódica a ser praticada por todo o exercitante que, assumindo seus pecados, desejasse redimir-se. A união dos dois mundos, diversos e separados, nada mais era do que a decorrência de uma união da criatura com criador. O plano da vivência religiosa definia e unia toda a humanidade (BARTHES, 1991, p.46).

Os Exercícios, elaborados para um universo europeu, passaram a ser utilizados para a conversão do gentio, sendo utilizados como parte do processo de catequização que guiava as criaturas perdidas do rebanho a se reencontrarem com Deus. O ideal de Cruzada, enquanto combate contra hereges e infiéis, transparece na sistematização dos Exercícios que repetiam, no plano religioso, a fidelidade dos cavaleiros para com o rei (Deus), um modelo sugerido explicitamente.

Loyola, de forma clara e objetiva, definia que a força motriz do processo de reaproximação da criatura com o criador era o da conversão para uma vida regrada, a qual estava na base do processo educacional do indivíduo que era também a do jesuíta. Se- guindo uma proposta rígida de conduta, o modelo deveria ser reproduzido. Esta missão deveria ser conduzida e impulsionada pelos reis escolhidos por Deus que, ao conquistarem a terra de infiéis, possibilitavam a reunião de toda a humanidade com o seu criador que Portugal com seus olhos bem abertos visualizou (LOYOLA, 1993, pp.65-66).

Aquele que guiava o exercitante ${ }^{2}$ deveria ser um facilitador da ação do Criador com a criatura e viceversa. A meta era reestabelecer a ordem primordial, perdida com o afastamento do Criador, sendo que a criatura deveria mostrar essa alteração, inclinando-se para a luz divina e para uma nova vida espiritual, muito próxima daquela descrita no Gênesis (LOYOLA, 1993, p.21).

É importante destacar que o pressuposto para compreender a existência humana nos Exercícios, estava atrelado à concepção bíblica de que as criações divinas foram concebidas para louvar a Deus. Assim, o princípio fundamental do modelo ideal, salientado por Loyola, entendia que o "homem é criado para louvar, reverenciar e servir a Deus Nosso Senhor, e assim salvar a sua alma". Por conseguinte, as demais coisas terrenas são concebidas como um elo de aproximação do homem com o ente divino, pois são "criadas para o homem", a fim de "que o ajudem a alcançar o fim para que é criado", que é servir a Deus e privando-se "delas tanto quanto dele o afastem" (LOYOLA, 1993, p. 28).

O mundo natural como parte do processo de ascese, manifestava-se de maneira a confirmar o

2. Os exercícios poderiam ser recebidos por intermédio de um religioso, ou realizados de forma direta pelo exercitante, daí sua exposição pedagógica e minuciosa. Pela ocasião da elaboração dos Exercícios Espirituais, a Companhia de Jesus não existia, portanto, o caráter aberto para qualquer religioso servir como mediador. Com a fundação da Companhia, esta função passa a ser exercida pelo jesuíta. 
criador. A natureza assumia, momentaneamente, sensibilidades que reforçavam a existência divina. Tendo como pressuposto a natureza como parte do processo de ascese, é que se deve compreender a ressonância das metáforas correlatas aos elementos naturais que dão sustentação à praxis jesuítica.

É com alegria e esperança que Antônio Pires ${ }^{3}$ ressalta o comportamento de um chefe indígena, que ao desejar a ação catequética jesuítica, afirmava:

"Vinde, muito folgo com vossa vinda, alegro-me muito com isto os caminhos folgam, as ervas, os ramos, os pássaros, as velhas, as moças, os meninos, as águas, tudo se alegra, tudo ama a Deus" (LEITE, 1954, vol. III, p.313).

Os Exercícios, enquanto diálogo com Deus, eram a confissão explícita de um pecado, o rompimento com Deus e a negação do divino ou do distanciamento em relação ao Criador (LOYOLA, 1993, p. 50).

Este ponto comum, de que o homem era um pecador pela sua condição mundana, da qual a confissão nada mais era do que um passo para a conversão, revela que o catolicismo esperava uma mudança de conduta, que os Exercícios reforçavam e tomavam como base para alcançar Deus.

Os povos recém-descobertos eram vistos pelos jesuítas como seres mergulhados numa cegueira nociva que, após a morte, desceriam ao inferno e por isso necessitavam de um cuidado específico para alcançar a salvação. Com efeito, conforme aborda Silva Dias:

\footnotetext{
"Havia agora a certeza de que o Evangelho ainda não fora anunciado a todos os homens. E não podia deixar de ser dramático, à luz das concepções teológicas dominantes, que nem a todos os homens tivesse sido dada a oportunidade de se salvarem através do baptismo" (DIAS, 1982, p.48).
}

3. Antônio Pires nasceu em Castelo Branco, Portugal, nos idos de 1519. Entrou para a Companhia, já Padre, a 6 de Março
As dificuldades eram muitas e a exigüidade de recursos, que afligiam os jesuítas, tende a comparar-se com aquelas que o casal Maria e José, pais de Jesus, padeceram em sua viagem por terras estranhas: fome, sede, calor, frio, injúrias e afrontas.

Os símbolos religiosos, utilizados para remeterem à associação com Deus, nesse primeiro contato cultural, envolviam diretamente elementos da natureza, geralmente em função dos atributos que Cristo recebeu do Pai divino. A natureza era cenário e meio para que a mensagem catequética se realizasse. E, conforme observou Theodoro ao analisar Exercícios Espirituais,

"A relação entre imagem, pensamento e palavra constituem a memória como sistema capaz de criar analogia entre signos de poder" (THEODORO, 1992, p. 59).

As imagens simbólicas atribuídas a Jesus na sua atuação junto ao gentio, para a propagação da seita cristã, seriam recuperadas totalmente pois, o gentio dos primeiros anos do cristianismo era tão hostil quanto aqueles encontrados nas novas terras. A ação benéfica de Cristo resida também em poder converter elementos do mundo natural em produtos diferentes da sua existência primeira. Assim, o jesuíta associou à sua prática por um processo de concatenação direta, ora a figura de um pastor, ora a de um agricultor, sintetizando nestas imagens o dom ofertado por Deus para a ação do homem junto à fauna e à flora.

O elemento indígena assume, dentro desta leitura, várias representações simbólicas: ovelhas perdidas, uvas de uma vinha que não produz bons vinhos, metáforas comuns e densas de significados que, além de se associarem aos escritos sagrados, revelam

de 1548. Chegou ao Brasil em 1549. Faleceu na Bahia a 27 de Março de 1572. 
como uma mentalidade jesuítica construiu ligações para unir os dois mundos, utilizando-se da natureza empírica que confirmava as verdades das Escrituras Sagradas. Rui Pereira ${ }^{4}$ relata aos Padres e Irmãos de Coimbra que:

"quantas razões temos de nos alegrar vendo que, além do fruto dos nossos trabalhos que na glória esperamos, vemos na terra criarem-se tantas plantas para o céu, e que gosta Deus delas tanto que parece que antes de serem de vez as colhe, e que não pode esperar dilação!” (LEITE, 1954, vol. III, p.298).

Tanto a terra como o céu eram povoados pelo mundo natural, com plantas de espécies variadas na terra, mas plantas iguais no céu.

A Bíblia, de maneira figurada, identificava o povo de Deus como ovelhas, e aqueles destinados ao cuidado delas, como pastores. A associação do jesuíta com a figura dos guardadores de rebanhos é uma imagem comum dentro das cartas, sendo que o gentio é inúmeras vezes classificado com um ser afastado do rebanho do Senhor.

Os jesuítas, identificando-se com a imagem do pastor Jeremias, que demonstra ser "uma cidade fortificada, como uma coluna de ferro e como um muro de bronze, sobre toda esta terra(...)", lançam as bases para que o catolicismo seja construído no Novo Mundo, funcionando como um cimento para a construção do edifício da cristandade.

Uma segunda associação da metáfora do pastor advinha da figura de Cristo, enquanto pastor de Deus na Terra. Os loiolanos companheiros de Cristo eram herdeiros de seus atributos, pois todas as imagens convergiam para um único ponto: Deus.

4. Rui Pereira nasceu em Braga, Portugal, nos idos de 1533. Entrou na Companhia a 23 de março de 1550. Chegou ao Brasil em 1559. Faleceu em data desconhecida.

5. Je. $1: 10$
Nas Epístolas ${ }^{6}$, Pedro, referindo-se à união íntima com Cristo, ressalta esta imagem aos homens dissociados do filho de Deus, afirmando que:

"Porque vós [humanos] éreis como ovelhas desgarradas, mas agora vos convertestes ao pastor [Cristo] e bispo das vossas almas".

Essa identificação de Cristo como pastor, segundo São João ${ }^{7}$, tinha sido sugerida por Jesus, ao afirmar:

"Eu sou o bom pastor. O bom pastor expõe a sua vida pelas suas ovelhas", concluindo que "Eu sou o bom pastor, conheço as minhas [ovelhas], e as minhas [ovelhas] conhecem-me."

Os jesuítas, enquanto companheiros de Cristo, configuram-se como parte dos atributos que aquele possuía, aptos e qualificados portanto, a pastorear o rebanho do Novo Mundo, servindo de meio para a promessa de Deus, que dizia:

"Eis que eu mesmo irei buscar as minhas ovelhas e as visitarei. Assim como um pastor visita o seu rebanho no dia em que se acha no meio das suas ovelhas [depois que andaram] desgarradas, assim eu visitarei as minhas ovelhas, e as livrarei de todos os lugares por onde tinham andado dispersas no dia de nublado e de escuridão" ${ }^{\text {. }}$.

O atributo de pastor não advêm da condição de missionário, mas sim da proposta de conversão que este pretendia realizar. Conforme sublinha Azpilcueta Navarro ${ }^{9}$, a persistência dos costumes gentios era decorrente da ausência de

"pastor que os metesse no curral da vida cristã, que é caminho de ouro, que é a glória onde nós todos esperamos de ir..." (LEITE, 1954, vol. I, p.178).

6. 1 Pedro 2:25

7. Jo. $10: 11 ; 14$

8. Ez. 34:11-12

9. Juan de Azpilcueta Navarro nasceu em Navarra entre 1521 e 1523. Entrou na Companhia a 22 de dezembro de 1545 e embarcou junto com a primeira expedição para o Brasil. Faleceu na Bahia a 30 de Abril de 1557. 
Por decorrência, o jesuíta é o meio pelo qual se efetiva, segundo Anchieta, a ação do Senhor que

"por sua misericórdia e bondade infinita quer reduzir algumas destas ovelhas perdidas ao rebanho de sua Igreja, e isto não com pequeno trabalho que com eles temos, predicando-lhes continuamente e trazendo-os por quantas vias podemos, porque es esta gente tão indômita e bestial, que toda sua felicidade tem posta em matar e comer carne humana, do qual pela bondade de Deus tenemos apartados estes:..." (LEITE, 1954, vol. II, p.120).

Os indígenas, considerados "ovelhas perdidas" as quais Deus quer incorporar ao rebanho da Igreja, conferem dilatada dimensão para a figura do pastor, que é o condutor dessa "gente tão indômita e bestial" ao "curral da cristandade".

A ovelha, dentre os animais, é mais vulnerável, por sua fraqueza e por sua incapacidade, de procurar alimentos sozinha, assim como de fugir de seus predadores. Desta forma, a ovelha é entendida pela falta de capacidade de agir de forma independente, assumindo além desta caracterização, e num sentido figurado, uma referência explicita às pessoas inocentes ou recém-convertidas, como exalta o Ir. Anchieta, ao afirmar:

“(...) já não é pouco fruto, antes o maior benefício de Deus, que entre tanta multidão de infiéis, algumas poucas ovelhas se abstenham ao menos de comer seus próximos." (LEITE, 1954, vol. II, p.110)

As demais ovelhas, espalhadas e desgarradas, estavam também sujeitas a toda sorte de malefícios, inclusive aqueles provenientes do Diabo. Por isso, nas Epístolas, Pedro dedicava especial atenção aos deveres dos pastores e dos fiéis, ressaltando:

"Sede sóbrios [pastores] e vigiai, porque o demônio, vosso adversário, anda ao redor, como leão que ruge, buscando quem devorar. Resisti-lhe, fortes na fé sabendo que os vossos irmãos, que estão espalhados pelo mundo, sofrem as mesmas coisas"10.

10. 1 Pedro 5:8-9.
O demônio, "inimigo dos homens", estava tão presente como Deus e era identificado normalmente como responsável pela não consecução da salvação humana; perspicaz e ardiloso, ele atuava diretamente na sociedade para impedir o êxito das obras cristãs, das quais os pastores inacianos eram guardiões e defensores.

Esta analogia do índio como a ovelha sugere de maneira indireta uma forma de percepção mediatizada pela Bíblia, que identifica, naqueles que não são cristãos, as fraquezas humanas sujeitas ao demônio, sendo que a ação dos pastores de Cristo era, segundo o Pe. Rui Pereira, "a restauração das ovelhas e castigo dos lobos"(LEITE, 1954, vol. III, p.300).

O Ir. Antonio de Sá ${ }^{11}$, relatando suas atividades na aldeia de Vitória, Espírito Santo, traça na sua narrativa a composição de um quadro catequético, onde o divino e o demônio guerreiam. Exaltando os êxitos obtidos pela conversão, Antonio de Sá ressalta a fúria do demônio, afirmando que este andava

"muito raivoso e indignado por ver que lhe temos [jesuítas] levado este ano tão grande prenda de almas, que na mortandade passada depois de ser batizadas levou o Senhor para si" (LEITE, 1954, vol. III, p.45).

Todavia, a persistência do demônio continuava, não deixando de existir com as conversões in extremis. Todo o ato de expansão da cristandade deparava com a presença de um demônio atuante. Isto leva o missionário a afirmar que:

"Mil impedimentos há posto o inimigo para que esta Aldeia de Vasco Fernandes não se ponha por obra, porque como determinamos de residir nela teme já a perda que há de receber com nossa [jesuítas] estada, ... " (LEITE, 1954, vol. III, p.45).

11. António de Sá nasceu pelos idos de 1537. Entrou na Companhia em 1559. Faleceu em data desconhecida. 
A escolha do sítio para Igreja e a casa jesuítica era, de forma simbólica, o triunfo da cristandade contra o demônio. Deus vencia o Diabo na terra dos brasis.

A presença de forças malignas nesta terra não impunha somente transtornos em nível material. Azpicuelta Navarro enfatiza esta ascendência demoníaca sobre o gentio, afirmando:

"Tem o Demônio muito domínio nelles, o qual dizem algumas vezes lhes apparece visivelmente e que lhes dá e atormenta outras vezes asperamente. Nosso Senhor nos livre de suas mãos" (CARTAS JESUÍTICAS, 1988, vol. II, p.97).

O Diabo, tão onipresente quanto Deus, estava dissimulado em multiformas, controlando uma série de entidades negativas que coabitam com os homens.

A ação jesuítica tinha salutar importância nessa luta terrena contra inimigos da cristandade, por vezes invisíveis. A tarefa do missionário jesuíta era lutar contra o demônio, que reinava num meio inóspito, influenciando desde a população que habitava a região, até a natureza. Seu fim último era purgar os males brasílicos.

Diego Laynes, por ocasião de sua investidura no cargo de Prepósito Geral da Companhia de Jesus, destaca a importância da obra jesuítica:

"A importância da obra se vê quanta seja, tratando não somente de conservar e ajudar os cristãos que já na fé tem princípio de sua salvação, como por aqui se faz, porém ainda de trazer muitos outros de novo, que do todo eram servos do demônio, e como ele filhos da ira e da perdição, ao estado da liberdade santa, e adoção dos filhos de Deus, e herdeiros com Cristo nosso Senhor de seu reino e felicidade eterna" (LEITE, 1954, vol. III, p.8). ${ }^{12}$

12. José Maria Paiva identifica esta concepção, como uma pastoral legalista, cabendo aos jesuítas "retirá-los [indígenas] da jurisdição do demônio e inserí-los na comunidade cristã ou, pelo menos, emprestar-lhes o figurino cristão, de modo que ao menos o território fosse legalizado"(PAIVA, 1982, p.62).
Em contrapartida, a imagem do pastor é caracterizada por uma vida difícil, pois deve cuidar para que suas ovelhas obtenham alimento e água, além de protegê-las dos seus predadores, para que não se tornem presas de animais ferozes. Muitas vezes, expondo-se às alterações climáticas e a perigos incomensuráveis, o pastor luta para manter o rebanho unido, gastando parte do seu tempo na procura daquelas ovelhas que se desgarraram ou se perderam, e é assim que a maioria dos relatos caracteriza a atividade missionária. A catequização se consubstancia, via de regra, pelo mundo natural.

O Pe. Azpilcueta Navarro, por ocasião de sua viagem a Porto Seguro, relata aos Padres e Irmãos de Coimbra, os perigos incomensuráveis para a ampliação da doutrina católica. Utilizando as imagens do pastoreio, destaca:

"Dali também ia visitar algumas aldeias ao derredor. Indo uma vez me houvera de afogar em um rio em o qual há pouco tempo que se afogou um Frade de Santo Antonio que ia desta mesma capitania pregar no sertão. Passei assaz de perigo por ser o rio mui corrente e enganoso de passar. Outra vez íamos a Vicente Rodrigues e levávamos em nossa companhia uma língua; fomos a umas aldeias alongadas que ainda não tínhamos visitado e no caminho passamos assaz trabalho e perigo, por nos ser necessário andar de noite algumas vezes e por matos, porque cá não há os caminhos de Portugal e há nelles muitas onças e outras feras" (CARTAS JESUÍTICAS, 1988, vol. II, pp. 95-96).

O Irmão Pero Correia, em carta ao Pe. Belchior Nunes, de 8 de junho de 1551, relata, por sua vez, a vida difícil de missionário na jornada para divulgação da fé católica, que começa com o preparo dos meios de transporte:

"Em esta jornada que fizemos, fomos alguns oito ou nove dias por um rio abaixo em casca de pau, e primeiro que tirássemos as cascas em que havíamos de embarcar se nos gastou o mantimento, porque nos pussemos a fazer almadias de um pau molle, e quebraram-se depois de feitas" (LEITE, 1954, vol. I, p.220-221) 
Os caminhos para conduzir as "ovelhas perdidas" ao "curral da cristandade" não eram tampouco fáceis de serem ultrapassados. Ressaltando-se a fragosidade da terra, os loiolanos evidenciaram as dificuldades em atravessá-la. Guerreiros do espiritual, lutavam contra as diversidades naturais do temporal.

A natureza inóspita impunha ao pastor barreiras concretas, que só a fé impelia à ação. António Blazquez, relatando a visitação feita à aldeia do Espírito Santo, na Bahia, destaca que para a realização e celebração do Senhor e do Espírito Santo foi necessária uma caminhada de seis léguas:

“...de aqui desta ciudad [Baia], el camino es parte por arenales, parte por lamaçales y charcos, el qual no se puede en ninguna manera andar sino descalços, que para gente poco devota no es pequeno impedimiento para dexar de lo hazer;..." (LEITE, 1954, vol. IV, p.73).

Como se não bastassem os empecilhos e as precariedades para a construção do edifício da cristandade, existiam ainda as deficiências da manutenção durante as investidas pelo sertão. Os caminhos contribuíam para dificultar a atividade do inaciano. Perigos incomensuráveis são vislumbrados, conforme afirma Pero Correia na mesma carta de 8 de junho de 1551:

"E assim fomos nosso caminho passando por aquele rio passos muito periguosos de saltos muitos que tinha em lugar de pedra, e a fome apertava conosco e comíamos alguns palmitos cozidos em água tal e algumas frutas bem desengraçadas, de maneira que quando chegamos a povoado levamos as cores muito demudadas" (LEITE, 1954, vol. I, p.220-221).

As armadilhas dos caminhos são intensificadas com a iminência da falta de alimentos para os andarilhos da fé. A fome, tão temida quanto os caminhos, era no âmbito do vivencial, a barreira mais difícil de ser transposta.
O Irmão Diogo Jácome ${ }^{13}$, em carta aos Irmãos de Coimbra, revelava as dificuldades da prática missionária no Novo Mundo, quase desconhecida daqueles que viviam num universo em que as esmolas dos devotos supriam a deficiência alimentar. Assim se pronunciava o loiolano aqui residente:

"Por estes caminhos padeceram os Irmãos com o Padre muito detrimento além do cansaço do caminho que levaram passando por rios a nado despidos, que dizem os Irmãos que entangessiam com o frio; e não tão somente isto mas muita fome em extremo, que não comião senão palmitos que achavam pelo mato com outras frutas de mais poco substância sem terem nem um grão de farinha de que lá chamais de pau." (LEITE, 1954, vol. I, p.245)

A atividade jesuítica era o palco de inúmeras privações, provações que constantemente o inaciano sofria na pregação da fé católica. Cada vitória contra a fome e o mundo natural confirmava indiretamente o domínio de Deus sobre a criação.

Os jesuítas eram sempre colocados à prova sendo a água a mais constante e sugerida em todos os discursos. A necessidade de deslocamento por terra ou mar fazia com que o inaciano enfrentasse, ora um rio colossal, ora tempestades mortais, situações marcadas por um padecimento em nome da fé, que poderia ser amenizado com a interseção divina.

Além disso, o tratamento médico das feridas destes pequenos animais fracos e inocentes, como eram vistos pelos loiolanos, era necessário, revelando outra faceta da dedicação missionária. A imagem do pastor é a de um homem bravo e valente, persistente e engenhoso, que antes de tudo pensa com zelo no bem-estar do seu rebanho. Tomando a iniciativa de se deslocar das terras européias para terras desconhecidas, demonstravam ser prestimosos na pro-

13. Diogo Jácome nasceu em Portugal e veio na primeira expedição para o Brasil. Faleceu no Espírito Santo a 10 de abril de 1565. 
cura dos necessitados e constituíam-se como modelos completos de uma conduta cristã pastoral.

A despeito disto, nem sempre a perseverança marcou a tônica do pastorear as ovelhas. Dificuldades e provações conduziram a um desânimo, revelado por alguns sinais de cansaço, logo após a euforia dos primeiros anos ${ }^{14}$.

Esta decepção, muitas vezes rotineira na prática jesuítica, consubstanciava-se através das visões do mundo natural. A não consecução dos objetivos previstos, sinalizados pela hostilidade do indígena e marcados essencialmente pela persistência de um padrão comportamental não cristão, levou, não raras vezes, a associar o comportamento indígena com aqueles praticados pelos animais ferozes e agressivos ao homem "gente tan mala, bestial y carnicera" (LEITE, 1954, vol. IV, p.147) ${ }^{15}$.

Caracterizados pela violência e agressividade para com os europeus, os jesuítas encontraram no mundo animal a exata medida simbólica que servia como elemento explicativo, facilmente assimilável, para delinear as similaridades do Outro - nativo -, mais próximo da natureza, do que da civilidade cristã européia.

As associações do indígena com os animais são variadas na sua representação metafórica. Tigres,

14. Os sinais de cansaço variaram segundo cada autor das cartas, o que não permite definir uma data para a compreensão deste aspecto. Cada loiolano isolado na sua aldeia ou vila demonstrou um desencanto com o êxito da conquista, deixando entrever que para eles a conquista era frágil e efêmera, por isso as suas solicitações por novos missionários é uma constante.

15. A associação com o comportamento animal não é atributo exclusivo de uma leitura do indígena. Baltasar Fernandes utiliza a mesma figura de linguagem para se referir aos colonos. Referindo-se aos indígenas pronuncia-se "Sam mui aborrecidos à gente branca, somente a nós, que os tratamos bem e os amparamos e livramos das unhas dos lobos, nos tem amor e se dam bem connosco" (LEITE, 1954, vol. IV, p.462). leões e lobos são os animais mais utilizados para caracterizar a força, agressividade e antropofagia dos brasis, com quem os inacianos deparam. Assim se revela o sentimento dos jesuítas que invariavelmente estavam sujeitos às investidas dos índios que eram "como tigres, que aora dan aquí, aora ally, y huiem con la presa en los dientes" (LEITE, 1954, vol. IV, p.172).

No entanto, os desabafos provocados pelo ressentimento da capacidade do gentio em compreender a palavra de Deus e buscar a salvação não significaram um desestímulo ao trabalho missionário. O número reduzido de jesuítas foi um dos principais problemas enfrentados pelos inacianos. A diversidade de tribos, dispersas por várias aldeias, constituíram um dos grandes empecilhos a uma ação eficaz e ampla do plano catequético.

O Irmão Pero Correia relata com pesar a falta de jesuítas, ao Pe. Simão Rodrigues. Após ter visitado povoações indígenas em busca de um cristão que vivia entre o gentio da terra, há mais de oito ou nove anos, e seguindo em conjunto com o Pe. Leonardo Nunez e mais cinco Irmãos, desabafa afirmando que voltavam "muito desconsolados por ver tantas almas perdidas por falta de quem as doutrine" (LEITE, 1954, vol. I, p.230).

As longas distâncias que separavam as aldeias das vilas impediam a divulgação da mensagem divina e o controle efetivo sobre os hábitos, costumes e padrões comportamentais do indígena, dificultando a conversão que, antes de mais nada, deveria ser comprovada através de uma prática repetitiva de sujeição.

A ausência de novos agricultores, para a vinha do Senhor, foi sentida desde os primeiros contatos, quando se apresentou de maneira mais clara o contraste entre a quantidade imensa de almas indígenas na escuridão a serem convertidas, e a quantidade ínfima de operários para tamanha messe. O Ir. Pero Correia, com pesar, lamenta a exigüidade de 
vindimadores, para o Pe. Belchior Nunes Barreto, concluindo:

"Há cá tanta miséria que se as houvesse todas de escrever, sei que lhe poriam grande mágoa em seu coração; mas as maiores são as destas pobres almas que por todo este Brasil e toda esta costa se perdem, em que haverá mais de duas mil léguas, se tudo gente que não conhece a Deus. Ora pois, caríssimo Padre, em tamanha vinha bem há o que cavar, mas faltam os cavadores" (LEITE, 1954, vol. I, p.223).

Faltavam lavradores para semearem as sementes da fé cristã na vinha do Senhor, ou como afirma o missionário Jorge Rodrigues, "semear a semente da palavra de Deus" (LEITE, 1954, vol. IV, p.277). Muito mais que uma metáfora, a simbologia utilizada pelos inacianos para expressarem seus posicionamentos sobre a estratégia da Companhia revelava que as necessidades na colônia eram bem diferentes daquelas existentes na Europa, onde o solo europeu já tinha presente as raízes do cristianismo. $\mathrm{Na}$ Europa faltava somente acabar de cultivar para realizar a vindima e nas novas terras as sementes ainda tinham que ser deitadas a um solo pouco fértil, para começarem a nascer as raízes da cristandade.

A necessidade fazia com que a formação educacional do jesuíta quanto às Letras fosse secundária, como destaca Azpilcueta Navarro:

"Approuve a Deus Nosso Senhor que chegassem os Padres mandados dahi, e esperamos que façam grande fruto com os selvagens como fariam outros si tivessem muita caridade e castidade de par com as forças corporaes para suprir as necessidades de tantos. As letras são menos necessárias, bem que entre os Christãos e entre os mesmos Gentios conversos, sejam as lettras precisas para a solução de casos diversos que entre elles se dão" (CARTAS JESUÍTICAS, 1988, vol. II, p.79).

Nóbrega, compartilhando da mesma opinião, justificava tal posição afirmando que o indígena era "todo papel branco e não há mais que escrever a prazer" (LEITE, 1954, vol. I, p.142).
Estes posicionamentos, sem dúvida pragmáticos, entendem que para terras tão dilatas, com duas mil léguas, ou mais, os cultivadores eram insuficientes. Precisavam de cristãos com uma vida regrada, independentemente de uma formação acadêmica, para as mais diversas atividades como mencionava António Blazquez:

"arrancar los cardos y espinas, ora en criar las nuevas plantas que crecen, ora en trajar que se tire coja algún fructo para el Senor" (LEITE, 1954, vol. IV, p.186).

Vicente Rodrigues sintetiza e delineia a pluralidade dos papéis dos futuros jesuítas agricultores:

"uns orando, outros chorando, outros cozinhando, de maneira que com tudo ajudeis e socorrais a tão miserável perdida de estas almas redimidas com o sangue do benditíssimo Jesus" (LEITE, 1954, vol. I, p.415).

A associação com a figura do agricultor é sugerida através da atividade da vinicultura. Nas narrativas bíblicas a videira, que já estava presente na terra de Canaã, era difícil de ser cultivada, requerendo um cuidado especial para obter boas uvas. Como símbolo, a uva (videira) é em sentido figurado, mencionada no cumprimento da profecia dos últimos dias, quando Cristo recolhe as videiras que simbolizavam os seus inimigos ${ }^{16}$.

O missionário, enquanto cultivador das vinhas, ou seja, dos inimigos/infiéis do Senhor, é responsável pela produção de boas uvas (cultivar/catequizar), para que estas produzam bons vinhos (a adoção do modelo cristão de conduta).

O projeto missionário, nesta perspectiva, via no gentio a representação do inimigo de Deus na iminência de precipitar-se no abismo infernal. Trata-se de uma visão salvacionista de missionários

16. Apoc. $14: 19,20 ; 19: 11-16$ 
guerreiros. O pensamento jesuítico entendia sua obra como uma luta contra o indígena, contra o mundo natural, em prol de Deus.

Em sentido também figurado, os recursos utilizados pelos inacianos foram sempre manipulados para marcar a negatividade dos tempos que antecedem a ação missionária e os benefícios que advêem da conversão. $O$ inimigo forte era paulatinamente destruído e a conquista era vista, passo a passo, nos escritos que construíam uma alteração comportamental muito mais desejada do que consolidada.

A conversão fundamental para o êxito da Companhia é consubstanciada a partir da alteração comportamental do gentio. Esta mutação, antes de ser um alteração rápida e concreta, foi percebida nas suas etapas parciais de adoção do modelo cristão, comprovadas principalmente no âmbito do mundo natural.

A religião católica, controladora do tempo e do espaço, ditava as normas para a ação do homem no mundo natural. A transformação do indígena de uma "gente tão indômita e bestial", para um rebanho de ovelhas, era necessária e implicava uma alteração do aborígene em relação à natureza. Como observou Koshiba " sob a aparência de queixa de um comportamento que desconhece o respeito a regras européias de boa conduta, oculta-se o sentimento de superioridade dos portugueses, que se colocavam como uma espécie de modelo ao qual se esperava ajustar-se o índio, para enfim admiti-lo como ser humanizado" (KOSHIBA, 1988, p.23).

Esta alteração, sinal concreto de uma batalha ganha, foi destacada com insistência. A mudança de comportamento em relação ao mundo natural é notada já por Azpilcueta Navarro, ao afirmar:

"Em toda a semana se ocupam em fazer roças para mantimentos (que antes ão faziam senão as mulheres). Guardam os domingos como nós o melhor, de maneira que em tais dias não fazem obra servil. Aconteceu em um dia destes haver ido uma menina ignorantemente a roça a trabalhar e, começando a trabalhar, veiolhe uma dor de barriga tão grande que houve logo tornar a casa. Entrando em casa, logo lhe dizeram que era festa, achou-se culpada de haver ido a roça” (LEITE, 1954, vol. I, p.179).

A desobediência aos ditames impostos pelo comportamento cristão implicava uma punição pela afronta que representava a fé católica. O respeito aos desejos divinos era fundamental, principalmente no que tocava às celebrações cristãs. O não cumprimento trazia malefícios que eram utilizados como exemplos edificantes para comprovar a onipotência de Deus.

O Irmão Vicente Rodrigues enfatiza este aspecto afirmando:

“Algumas vezes vão às suas roças, que é o seu mantimento, ao domingo e festas, onde os mordem bichos assi como bibaras, das quaes alguns morrem. As quaes cousas e outras mais particulares lhe succedem em tempos que lhes dá muito que cuidar e tirar de seus erros,..." (CARTAS JESUÍTICAS, 1988, vol. II, p.135).

O modelo europeu de cristandade intervinha no ritmo da vida das tribos, reordenando-o e impondo limites e permissões ao tempo e ao espaço que se justificavam em função da religião. A Bíblia impunha o compasso da vida ao mundo natural. Ser cristão era não só professar a fé católica, mas sobretudo estar atento a um conjunto de padrões impostos e definidos por Deus, desde a origem da humanidade. Ser cristão era não ir às roças aos domingos, pelo medo das punições divinas. Ser cristão era, sobretudo, aprender que a natureza deve ser cultivada, pois o cristianismo era uma civilização da cultura.

Esta simbologia, utilizada pela Bíblia e apropriada pelo pensamento jesuítico, tinha como objetivo principal e último dar orientação ao gentio para que ele pudesse ser inserido na civilidade cristã. A conversão significava não só introjetar bons hábitos de conduta moral católica, mas também uma nova relação com o mundo natural. A desordem do sistema do Novo Mundo aproximava-se do fim. A nova or- 
dem era, a partir dos descobrimentos, a ordem católica, que se iniciava com a própria ocupação do espaço geográfico.

Em suma, o mundo natural para os primeiros jesuítas era uma realidade cotidiana indissociável da verdade absoluta de que Deus tinha sido o seu cria-

\section{Bibliografia}

ANCHIETA, José de, S.J. Cartas. 2a . ed. São Paulo, Loyola, 1984. AZZI, Riolando. A cristandade colonial: um projeto autoritário. São Paulo, Edições Paulinas, 1987.

BARRETO, Luís Felipe. Os descobrimentos e a Ordem do Saber. Lisboa, Gradiva, 1987.

BARTHES, Roland. Sade, Fourier, Loyola. Paris, Seuil, 1991.

CARVALHO, Joaquim de. Estudos sobre a cultura portuguesa do século XVI. Coimbra, Universidade de Coimbra, 1947.

DELUMEAU, Jean. A Confissão e o Perdão. Tradução de Paulo Neves, São Paulo, Companhia das Letras, 1991.

DIAS, José S. da Silva. Os descobrimentos e a problemática cultural do século XVI. Lisboa, Editorial Presença, 1982.

FEUERBACH, Ludwig. A Essência do Cristianismo. Tradução de José da Silva Brandão, Campinas, Papirus, 1988.

GAMBINI, Roberto. O espelho índio. Rio de Janeiro, Espaço e Tempo, 1988.

HOLANDA, Sérgio Buarque de. Visão do Paraíso. $5^{\mathrm{a}}$ ed. São Paulo, Brasiliense, 1992.

HOORNAERT, Eduardo e outros. História da Igreja no Brasil. $4^{\mathrm{a}}$ ed. Petrópolis, Vozes/Edições Paulinas, 1985.

KOSHIBA, Luis . A Honra e a Cobiça. Tese de Doutorado apresentada à Faculdade de Filosofia, Letras e Ciências Humanas da Universidade de São Paulo (Depto. de História), 1988.

LÉCRIVAIN, Philippe, S.J. Les missions jésuites. Paris, Gallimard, 1991.

LEITE, Serafim, S.J. Cartas dos primeiros jesuítas do Brasil. São Paulo, Comissão do IV Centenário da cidade de São Paulo, 1954, 4 volumes. dor e deveria ser louvado por isso. O espetáculo da natureza, quando ocorria, processava-se principalmente em função e no âmbito do divino, que dava eco à ação missionária. Por outro lado, a natureza é algo que o loiolano tenta suportar, controlar ou vencer para a concretização do ato catequético.

História das Companhia de Jesus no Brasil. Lisboa/Rio de Janeiro, Portugália/INL, 1938/1949, vols. I e II.

LENOBLE, Robert. Histoire de l'idée de nature. Paris, Albin Michel, 1990.

LOYOLA, Inácio. Exercícios Espirituais. Trad. de Joaquim F. Pereira, São Paulo, Loyola, 1993.

NEVES, Luiz Felipe Baeta. O Combate dos soldados de Cristo na Terra dos Papagaios. Rio de Janeiro, Forense, 1978.

O'GORMAN, Edmundo. A invenção da América. Trad. de Ana Maria Martinez Corrêa e Manoel Lelo Bellotto, São Paulo, UNESP, 1992.

PAIVA, José Maria de. Colonização e Catequese. São Paulo, Cortez, 1982.

THEODORO, Janice. América Barroca. São Paulo, Edusp, 1992.

TURNER, Frederick. O Espírito Ocidental contra a Natureza. Trad. de José Augusto Drummond, Rio de Janeiro, Campus, 1990.

THEVET, André. Singularidades da França Antártica (1558). Trad. de Eugenio Amado, Belo Horizonte/São Paulo, Itatiaia/ Edusp, 1988.

VASCONCELOS, Simão de. Crônica da Companhia de Jesus (1663). Petrópolis, Vozes, 2 volumes, 1977.

Cartas Jesuíticas I (1549.1560). Belo Horizonte/São Paulo, Itatiaia/Edusp, 1988.

Cartas Jesuíticas II (1550.1568). Belo Horizonte/São Paulo, Itatiaia/Edusp, 1988. 